\title{
Beyond Planning: Markets and Networks for Better Aid
}

\section{Owen Barder}

\section{Abstract}

The political economy of aid agencies is driven by incomplete information and multiple competing objectives and confounded by principal-agent and collective-action problems. Policies to improve aid rely too much on a planning paradigm that tries to ignore, rather than change, the political economy of aid. A considered combination of market mechanisms, networked collaboration, and collective regulation would be more likely to lead to significant improvements. A "collaborative market" for aid might include unbundling funding from aid management to create more explicit markets; better information gathered from the intended beneficiaries of aid; decentralized decision-making; a sharp increase in transparency and accountability of donor agencies; the publication of more information about results; pricing externalities; and new regulatory arrangements to make markets work. The aid system is in a political equilibrium, determined by deep characteristics of the aid relationship and the political economy of aid institutions. Reformers should seek to change that equilibrium rather than try to move away from it. The priority should be on reforms that put pressure on the aid system to evolve in the right direction rather than on grand designs.

\section{Working Paper 185 October 2009}




\title{
Beyond Planning: Markets and Networks for Better Aid
}

\author{
Owen Barder \\ owen@devinit.org
}

October 2009

Thanks to Nancy Birdsall, Michael Clemens, Andrew Rogerson, Alan Hudson, Stephen Groff, Dan Nielson, Adrian Wood, David Bonbright, Karin Christiansen, Tim Harford, Paul Isenman, Alex Jacobs, Laurie Lee, Bill Savedoff; colleagues at Development Initiatives; and the participants in a seminar at the Center for Global Development in Washington, D.C., in April 2009. This paper has benefited enormously from ideas and insights from many officials from several aid agencies, who have to be anonymous.

This paper was made possible by financial support from the William and Flora Hewlett Foundation.

Owen Barder. 2009. "Beyond Planning: Markets and Networks for Better Aid.” CGD Working Paper 185. Washington, D.C.: Center for Global Development. http://www.cgdev.org/content/publications/detail/1422971

Center for Global Development 1800 Massachusetts Ave., NW Washington, DC 20036

202.416.4000

(f) 202.416 .4050

www.cgdev.org
The Center for Global Development is an independent, nonprofit policy research organization dedicated to reducing global poverty and inequality and to making globalization work for the poor. Use and dissemination of this Working Paper is encouraged; however, reproduced copies may not be used for commercial purposes. Further usage is permitted under the terms of the Creative Commons License.

The views expressed in this paper are those of the author and should not be attributed to the board of directors or funders of the Center for Global Development. 
1. Aid works, but it could work much better. Reform of aid is needed to prevent aid from doing damage to institutions in developing countries; to ensure that aid is effectively used for poverty reduction; to reduce proliferation and transaction costs; to increase predictability; to encourage more learning and improvement; and to focus on results rather than inputs.

2. Over four decades donor agencies have repeatedly committed themselves to change, but reform has been slow. D eveloping countries express their frustration that donors are failing to live up to their commitments, and public confidence is sapped by a succession of books and articles pointing out the deficiencies of the system.

3. Aid agencies exist to reduce poverty, often amongst other objectives; but the reason we have aid agencies rather than transferring money directly to the poor is to mediate the different interests of the donor and the recipient; to reduce the problems of incomplete information; to reduce transactions costs; and to obtain the benefits of scale. The proliferation of aid agencies with diverse interests complicates collective action, which make it difficult to secure benefits of cooperation. Aid agencies suffer from principal-agent problems, much like other public sector organisations but exacerbated by long delivery chains. A particular challenge for aid is that there is a broken "feedback loop" connecting the intended beneficiaries and decision-makers.

4. These constraints cannot be overcome by wishing that they did not exist. Progress does not require "thinking outside the box": rather we have to understand the box and take steps to reshape it. The aid system converges on an equilibrium determined by deep characteristics of the aid relationship and the political economy of aid institutions. This paper argues that reforming aid requires finding ways to change that equilibrium, rather than trying to move away from it. If donors try to make changes that are not consistent with the underlying political economy of aid, there is a danger that, far from improving aid, such measures will not be implemented and, to the extent that they are, they will result in declining support for aid.

5. The existing agenda for aid effectiveness, for example set out in the Paris and Accra declarations, has much to commend it. But efforts to implement these changes have been dominated by the planning mindset. Long coordination meetings among donors and with developing country governments do nothing to change the institutional and political constraints within which aid agencies operate. Organisations may commit themselves in principle to respect country ownership and leadership, to contain proliferation, or to make aid more predictable but they can do none of this if it is not in their interests or if there are political constraints which prevent it. There is no authority that can force donors to stick to their commitments, and even the embarrassment of breaking international agreements has limited traction, especially when most other aid agencies are similarly in default. Greater respect for country ownership or a better division of labour of donors may the eventual result of improvements in the aid system, but we are reaching the limit of how much progress can be made by international statements of intent and coordination meetings. 
6. Apart from planning, there are two other types of institutional approaches to coordinating multiple actors with diverse and competing interests: mark ets and networks. These forms of coordination can improve accountability, reduce information asymmetries, and reduce principal-agent incentive problems. They can therefore help to change the political economy of aid, and so move the political equilibrium. More transparent organisations operating with more explicit contracts in a regulated competitive marketplace, supported by networked collaboration, would find it easier to implement the aid reform agenda.

7. Taken together, these changes might be called a oollaborative market. This is shorthand for a market governed by collective regulatory agreements and complemented by symmetric and accessible information. Specific measures to move towards a collaborative market could include unbundling funding from design and implementation of aid programmes, to create explicit markets for aid delivery; improving international competition in the supply of development services; new standards for aid transparency; mechanisms to allow aid beneficiaries to provide feedback about the services they receive; penalties for negative spillovers (such as entry fees to discourage proliferation) and subsidies for positive spill-overs (such as independent and rigorous evaluation); and the establishment of a more effective regulatory mechanism, backed if necessary by treaty.

8. It is not certain that these measures would be sufficient to overcome the challenges of the aid system and so make aid more effective. The problems may be too difficult to budge. But reforms that are framed around changing the political incentives will, over time, be much more likely to succeed than reforms which ignore the fundamental reasons why aid agencies act as they do.

9. Donors might move towards a collaborative market because the reforms are politically attractive in their own right, because they recognize the need to solve a collective action problem, and because it is in their long-term interests to do so. Agreeing and enforcing new rules of the game will not be straightforward, but this approach is more likely to succeed than trying to coordinate every development intervention in long planning meetings among a growing number of donors.

10. Improvements in the institutions of international aid are more likely to come from evolution than from intelligent design. Evolution requires a combination of variation and selection, and so reforms should build incentives to innovate and improve, and to screen out unsuccessful institutions and approaches.

11. This agenda builds on approaches that are already being explored, for example to increase the empowerment of beneficiaries; to untie aid; to increase transparency and to improve independent evaluation. Although these approaches are not new, they are pursued piecemeal: we have not had a shared view of how those reforms fit together and where they might lead to. There are three key propositions on which the argument for collaborative markets is based:

a. Aid institutions are in a kind of political equilibrium balancing the interests of donors and recipients. Reform efforts that simply move away from equilibrium will 
not be implemented or sustained, and may do more harm than good. To have effective and sustainable reforms we need to try to change the political equilibrium.

b. We are reaching the limits to what can be achieved by better planning to improve aid. Greater use of market and network mechanisms, by contrast, would help to alter the incentives and political constraints faced by aid agencies.

c. In the long run, improvements in the aid architecture are likely to be the result of evolution not design. Reform should focus not on a grand new design of the aid system, but a set of technical and apparently innocuous reforms which, over time, create stronger political pressures for evolutionary improvements in the aid system.

12. This is a call to action, not a counsel of despair. We must recognize the realpolitik of aid, but we can also help to change it. D eveloping countries demand that aid should be delivered better and be more responsive to their priorities, but donors are not responding rapidly enough. By investing in greater transparency and accountability of aid agencies, making more use of market and network mechanisms and closing the feedback loop we can change the context in which aid agencies operate and make faster progress on reducing poverty.

13. This approach calls for greater use of market mechanisms, but recognises that market mechanisms alone will not solve the problems of aid. Market mechanisms should be complemented by international cooperation on a regulatory frameworks, and investments in networked collaboration to increase access to information and draw on the wisdom of crowds, especially to link the experiences of beneficiaries to decision-makers. The policy measures proposed at the end of the paper are intended as examples to illustrate these principles, rather than to promote a specific policy agenda. 


\section{THE NEED FOR MORE EFFECTIVE AID}

14. Aid is not the most important determinant of how quickly a country develops. Nonetheless, aid can contribute both to accelerating development, and to improving the lives of people in developing countries while that process is taking place. There is considerable evidence that aid works, but not as well as it should. The aid system suffers from a series of chronic structural problems which have been repeatedly shown to reduce the effectiveness of aid. They have been well documented and widely recognized, many of them for three decades or more. ${ }^{1}$ Aid donors have declared their intention to address these problems but progress has been very slow.

15. The problems of aid can be summarised under five headings:

a. Aid can impact negatively on institutions and accountability in developing countries. Aid can undermine the "social contract" between the state and its citizens and close down policy space within developing countries. D elivered badly, aid can potentially stifle the emergence of capable and accountable states. (See Moss et al, 2006; Brautigam \& Knack, 2004; Knack, 2001; Djankov, Montalvo \& ReynalQuerol, 2008; Wood, 2008).

b. The reduction of poverty is compromised by pursuit of broader interests. Donors (both policy-makers and the taxpayers that they represent) have multiple objectives for foreign assistance, such as commercial, strategic, security and ideological interests, which distort aid allocations from where the money will do most good and use it in ways that do not have the biggest impact (Alesina \& D ollar, 1999). Furthermore, poverty reduction is a complex, multi-dimensional problem and different organisations have different priorities (Barder, 2009).

c. Proliferation, transactions costs and administration costs reduce the value of aid . The proliferation of aid agencies and projects, together with the way that aid is managed, can lead to large overheads on both donors and recipient countries (Acharya, de Lima, \& Moore, 2004). (Competition and diversity are advantages, but only when the system drives out inefficient or ineffective organisations and forces organisations to reduce their costs and improve their performance.)

d. Short-termism and lack of predictability reduces the effectiveness of aid. There is considerable evidence that the value of aid is significantly reduced by shorttermism and unpredictability, which negatively affects both the efficiency of aidfinanced spending, and has negative macroeconomic consequences (Bandyopadhyay $\&$ Wall, 2007). One estimate puts the cost of aid volatility as about $22 \%$ of the value

1 The Pearson Report (1969) set out many of the challenges that still confront aid forty years later. See box below. 
of the aid (Kharas, 2008). The system has not hit on the right combination of flexibility and predictability.

e. There is insufficient focus on results, and not enough evaluation, learning and feedback. There is too much focus on inputs. There is too little rigorous evaluation, too little testing of new ideas; successes are rarely taken to scale; failures are not learned from and abandoned (Easterly, 2007). Rigorous evidence of results and impact is not collected and communicated (Savedoff, Levine \& Birdsall, 2006; Banerjee et al, 2007).

16. Policy proposals for improving aid all attempt to address to one or more of these challenges. For example, efforts to untie aid ${ }^{2}$ would increase the value of aid for poverty reduction, but progress is hindered by commercial interests in donor countries. Technical assistance - which has been repeatedly shown to be badly managed by donors, despite its potential importance in developing countries - suffers from high transactions costs, shorttermism, pursuit of multiple objectives, and inadequate focus on results, and yet for forty years it has defied donors' frequent commitments to reform.

17. These shortcomings do not mean that aid is ineffective overall. On the contrary, there is a rich empirical literature on the impact of individual aid-financed interventions, and on the overall positive correlation between aid and economic growth. In particular, Clemens et al (2004) demonstrate a positive correlation between aid that is intended to lead to economic growth and higher rates of growth in developing countries. (See also Burnside \& Dollar, 2000; Dalgaard, Hansen \& Tarp, 2004; Hansen, 2004; Radelet, 2006; Roodman, 2007; Minoiu \& Reddy, 2009). But aid could be made substantially more effective if these problems were addressed. Minoiu \& Reddy (2009) find evidence that aid works, but that aid from agencies that suffer fewer of the problems listed here is more effective.

18. Developing countries have become increasingly vocal in their calls for reform of donor behaviour. They have pressed the case for greater policy space; for aid to be untied from the commercial interests of donors; for aid to be more predictable and transparent; and for donors to make more use of developing country systems.

19. The Pearson Commission identified almost all the components of today's aid effectiveness agenda as long ago as 1969 (see box below for details). Since the Marshall Plan donors have committed themselves to improving the way that they give aid. The donor club at the OECD, the Development Assistance Committee (DAC), produces guidelines for donors which donors are, in principle, committed to observing. O ver the last decade donors have committed themselves to improving aid in the DAC Guidelines on Poverty Reduction (2001), the Monterrey Consensus (2002), the Rome Harmonization Agenda (2003), the Paris D eclaration (2005) and the Accra Agenda for Action (2008).

2 "tied aid" is the practice of linking aid to a requirement that goods or services be purchased from the donor country 


\section{"Partners in Development": The Pearson Commission Report (1969)}

In 1969 a Commission chaired by Canadian $\mathrm{N}$ obel prizewinner, L ester Pearson, produced a report, "Partners in D evelopment" which called for a better partnership, a clearer purpose, and greater coherence in development aid by linking aid to the development objectives of the recipients of aid. "Partners in D evelopment" also called for aid to be made more effective by untying aid, allowing aid to be used for purchases in other developing countries, and providing programme funds instead of project aid; and it called for a reform of technical assistance and provision of stronger institutional support. It also argued that the proliferation of aid organisations was unsatisfactory and that there should be a clearer division of labour, greater coherence within the aid machinery, and greater use of multilateral institutions. It argued that there should be greater oherence between development policies and other policies of wealthy countries.

20. In principle these problems could ameliorated if donors simply chose to live up to their existing commitments to improve the way that they give aid. The necessary steps have been identified and donors have committed themselves to change. Yet progress has been extremely slow. According to the 2008 survey on implementation of the Paris Declaration only $45 \%$ of aid goes through domestic country systems: the rest goes through parallel processes which undermine the domestic system. There is no discernible link between the quality of a country's systems and whether donors use them. The DAC estimates that just $57 \%$ of aid is "country programmable": the rest is spent outside the control of the recipient country. Aid remains unpredictable: only a third of aid is disbursed on schedule, making it impossible for governments to plan. In 2007, 54 countries received more than 14,000 donor missions - an average of 260 missions a year. Vietnam benefited from 752 donor missions more than three a day (OECD D AC, 2008a). As the graphs below show, the average size of project has been dwindling, while the number of projects has increased. ${ }^{3}$
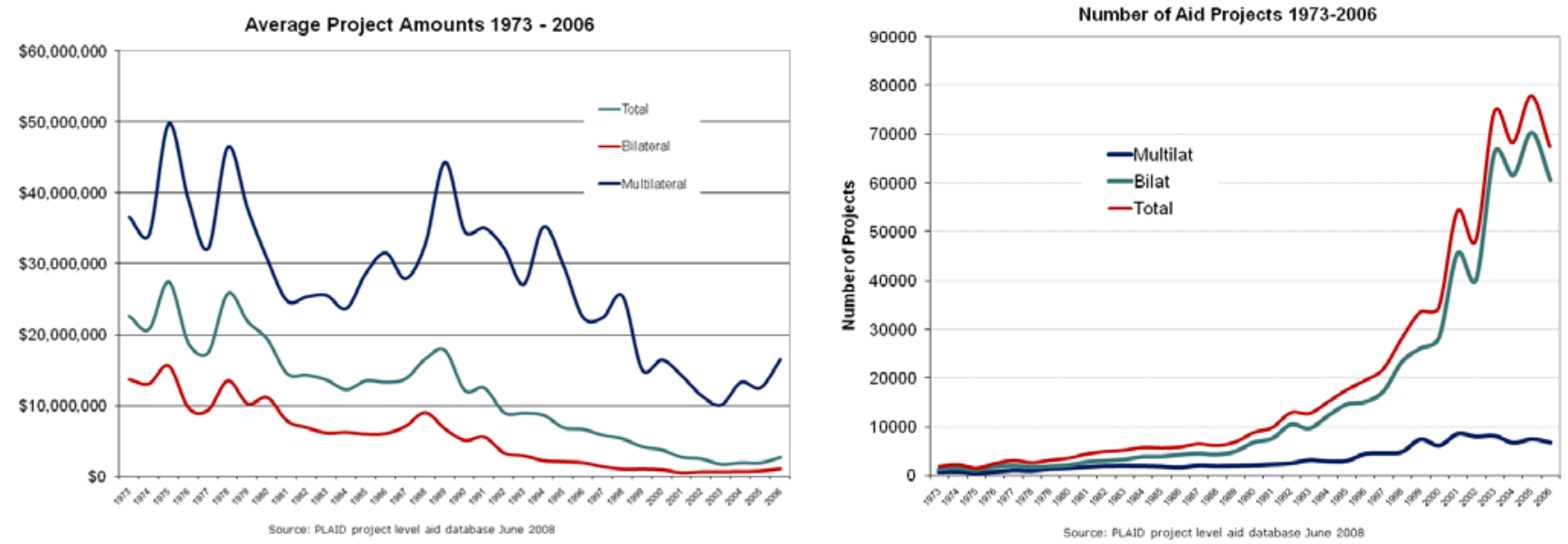
22. Developing country partners are increasingly angry that donors are failing to live up to their commitments. The Monterrey Consensus was conceived as a grand bargain between donors and developing countries, and it is becoming a source of considerable irritation that developing countries have made better progress on their commitments than donor countries have made on their side of the bargain.

23. Declarations of intent have clearly not been sufficient to overcome the political and institutional incentives and constraints within which donors work. The staff and leadership of donor agencies want to make aid work better but they operate within an institutional and political context which makes it very difficult for them to make progress. There have been studies of incentives within aid agencies (see especially Ostrom et al, 2002), but these incentives will not change until the incentives and constraints faoed by the agencies themselves are changed.

24. This paper seeks to understand the institutional determinants of, and constraints upon, the behaviour of donor agencies and then to design an institutional framework within which agencies are more likely to act in ways that increase their impact on development and poverty reduction.

\section{WHY DO AID AGENCIES EXIST?}

27. If individuals in rich countries want to help people abroad, why don't they simply give money directly to people in developing countries, for them to buy private goods such as food and shelter, and to the governments of developing countries for them to provide public goods such as security and infrastructure? Why do we need donor agencies to connect the donors and the intended beneficiaries?

25. Aid agencies exist for many of the same reasons that firms exist, namely that we live in a world of imperfect information, diverse objectives, increasing returns to scale, and transactions costs. ${ }^{4}$ Aid agencies, acting as intermediaries between the givers and the intended beneficiaries, reduce the costs of delivering aid by:

a. mediating between the competing interests of donors and recipients, and the interests of the various individuals and organisations in the aid delivery chain;

b. reducing transactions and information costs, by reducing uncertainties in delivery by monitoring performance, and so managing the challenges of incomplete and asymmetric information;

4 This discussion draws on a branch of economic thinking called New Institutional Economics. This covers a broad range of issues, which looks at how organisations manage tasks in a world of imperfect information, transactions costs, property rights, incomplete contracts. See Williamson (2000) and North (1990). Easterly (2002) and Ostrom (2002) apply the institutional economics of bureaucracy to aid. 
c. achieving returns to scale in aid management, including gathering and communicating information, acquiring knowledge, expertise, and reputation, and establishing systems for transmission of resources.

"T he archetype of intermediation in foreign aid is the missionary, who mediates between potential donors in their home town and potential recipients in their mission town. Individual missionaries as well as missionary organisations may generate two types of savings in transaction costs:

- They reduc real transadions costs through economies of scale in search costs: information and appreciation of the plight of the potential recipients and transmission of information to potential donors

- They reduœ ex -post unœertainty by ensuring preferenœ alignment between donor and recipient communities. Missionaries apply the moral and religious values of their community of origin to select redipients in their missionary community."

Bertin Martens, Why D o Aid Agencies Exist? (2005)

26. An example of the role of an intermediary is the missionary (see box above) who channels aid from a home community to the intended beneficiary. This does not mean that aid agencies are like missionaries, or should aspire to be so. But it provides a graphic illustration of the reasons why we create intermediaries to deliver aid on our behalf.

27. This analysis helps to explain why aid agencies exist at all. But why is there more than one aid agency? The answer is that the providers of aid have diverse and sometimes conflicting objectives (see Alesina and D ollar, 1999; Bandyopadhyay \& Wall, 2007; Collier D ollar, 2002; Easterly \& Pfutze, 2007; Milner, 2004; O strom et al, 2002).

28. D onor agencies often identify poverty reduction as their primary objective, but in practice most are also asked to pursue an additional set of national objectives such as promoting national security, commerce and prestige.

29. As I have argued elsewhere, poverty reduction is not a single objective but a set of goals, some of which are complementary but among which there are also important trade-offs for example about which people are helped, in which ways, and when (Barder, 2009). Different donors (even different parts of the same donor agency) may attach different importance to different aspects of poverty reduction.

30. Furthermore, donors have different and sometimes contradictory views about how poverty reduction can be achieved: for example, one donor may use its aid to promote private sector provision of public services while another donor may favour public provision. Many donors tend to promote institutional changes that reflect their own experiences and institutional context. 
31. Even to the extent that there is agreement on any particular objective and how it should be achieved, each donor may have slightly different priorities for its role in contributing to it. For example, most donors seek to demonstrate a link between their own funding and a particular output or outcome, and they are willing to forgo a certain amount of poverty reduction in return for being able to take credit for the impact.

32. Because donors have broader objectives than just poverty reduction, they are also likely to compete with each other directly. For example, donors that use aid not only to reduce poverty but also to build market share for their exports, to improve strategic relationships with a recipient country, or to secure a greater proportion of the supply of natural resources, are pursuing objectives that directly compete with the corresponding objectives of other donors.

33. So we have multiple aid agencies, rather than just one, because donors have heterogeneous preferences: they have different overall objectives for poverty reduction, different preferences about how those poverty reduction goals should be reached, and a range of other competing objectives that they pursue through their aid programmes.

34. But the existence of a set of aid agencies with diverse preferences - some of which are incompatible - creates a new series of challenges. In particular, it creates a set of principalagent problems within the organisations, and collective action problems between them.

35. All organisations suffer from principal-agent problems. This is economists' way of saying that the interests of the staff of the organisation are not exactly the same as the interests of the owners or the funders, and with imperfect information and incomplete contracts it is not always possible to ensure that the interests of the funders are being fully pursued. Principalagent problems are typically compounded in a public administration because (a) public organisations generally try to manage multiple objectives; (b) there are more difficult problems measuring output and performance in the delivery of public services than there are in strictly commercial enterprises; and (c) it is usually more difficult to create effective performance incentives in public organisations (Bendor, 1988; Moe, 1997). In aid delivery the principal-agent problems are exacerbated by long delivery chains. Aid will frequently pass from the donor to multi-donor consortiums, to managing agents and implementing agents before it reaches the ground; and each of these organisations has its own interests that it will pursue alongside the goals of the funder.

36. The ollective action problem between aid agencies is an inevitable consequence of the diversity of preferences among donors and between donors and recipients. There would be no collective action problem if the impact of each aid agency were independent of the actions of others. But there are many spill-overs between aid agencies, both positive and negative. (A "spill over" effect occurs if the decisions of one person or organization impacts on the objectives of another person or organization.) Many aid interventions require collaboration between donors (e.g. filling a financing gap, providing debt relief, or designing economic reform programmes). There are positive spill-overs if aid interventions complement each other. For example, a clinic funded by one donor will be more effective if it is well served by a road, which may be funded by another donor; a scheme to promote small businesses will do better if schools improve (Sachs, 2005b). There are also many 
negative spill-over effects in aid. For example, as aid agencies proliferate, transactions costs are increased; the effectiveness of conditionality is reduced; institutional capacity is reduced; markets for scarce skills become tighter; and economies of scale are foregone. Maximising the overall benefits of aid therefore requires some form of cooperation between the donor agencies and with developing countries to encourage positive spill-overs and minimise negative spill-overs. The collective action challenge is that this cooperation must be organised among agencies with different and sometimes competing objectives ( $\mathrm{O}$ strom et al, 2002).

37. Cooperation is difficult to enforce when the actors are sovereign governments with no obligation to defer to each other. O ne way to improve cooperation between individuals and organisations when there are repeated interactions is through reputation effects, which create incentives to cooperate. Economic theory tell us that reputation effects are most likely to be effective at enforcing cooperation when there are relatively few players, and when there is a high degree of transparency about their decisions and actions (North, 1990). Current trends in the aid industry towards greater proliferation of actors, with slow progress on improving transparency, suggest that reputation effects are likely to become less effective at enforcing cooperation.

36. The missionary in paragraph 26 exists to solve two problems: mediating the interests of the givers and the receivers, and reducing transactions costs. In the modern aid environment, the first of these challenges is complicated because there are three sets of competing interests that the aid system has to mediate: the difference between the interests of a donor and a recipient; the difference between the interests of one donor and another donor; and the difference between the interests of a funder (e.g. a donor government) and the implementing agents (e.g. an aid agency or NG O , or institutions in the developing country).

37. It is tempting to conclude that the answer is for donors to defer to the leadership of developing country governments, especially given the commitments to this in the Paris D eclaration and the Accra Agenda for Action. But that assumes away the problem. The balance of power between donors and recipients converges on an equilibrium which balances the various interests of the givers and receivers of aid, and the implementing agents. If we find this equilibrium unsatisfactory, we have to change the determinants of the equilibrium, not simply try to move away from it.

38. There is one additional challenge which is particularly acute for aid administration (as compared to most other public service organisations): there is a geographical and political separation between donors and beneficiaries which gives rise to a brok en feedback loop. Citizens in donor countries have no direct knowledge of the programmes financed by the aid agency, and it is prohibitively expensive to obtain information about those programmes. The intended beneficiaries have no political leverage over the politicians in the donor country who approve the programmes. The result is that decision-makers have very poor information about, and no accountability to, the intended beneficiaries of aid. (Some NGOs play an imperfect but important role in filling this gap.) By contrast, in a country that finances its services by taxation, the managers of public services are accountable to 
politicians who are in turn accountable to the public that pays the taxes and whom those services are meant to serve. That feedback loop is largely absent in foreign aid, because there is a lack of both information and political influence connecting decision makers to the intended beneficiaries.

39. We have thus identified four realities of the political economy of aid:

a. aid suffers from imperfect and asymmetric information, and especially a broken feedback loop from the intended beneficiaries to the decision-makers;

b. aid agencies exist to mediate multiple objectives of key stakeholders, both between donors and recipients and between different donors, as well as to reduce the problems of imperfect information; and to obtain the benefits of returns to scale;

c. aid agencies suffer from principal-agent problems, typical especially in the public sector and exacerbated by long delivery chains;

d. there are problems of collective action between aid agencies with diverse and competing objectives, which make it difficult to secure positive spill-overs and minimise negative spill-overs.

40. These problems are not the result of policy choice: they are inherent characteristics of the aid relationship. The broken feedback loop, in particular, is a problem largely peculiar to foreign assistance. The five challenges of aid identified in section one can each be directly traced to these four realities of political economy. For example, the focus on inputs rather than results is a common consequence of the principal-agent problem in an environment in which inputs are easier to monitor than outputs. Tirole (1994) uses a principal-agent model to show that government agencies producing multiple outputs will focus their efforts on the observable ones. Proliferation of donor projects is the result of a collective-action problem in which every donor has an incentive to have a presence in every sector in every country. (The table on the following page illustrates the links between the four political economy problems listed in paragraph 37 and the five challenges of aid effectiveness listed in paragraph 15.)

"T he art of institutional design is to ensure that, despite the variety of motives of agents to whom task s were delegated, the end result remains as close as possible to the original intentions of those who established the organisation."

Bertin Martens (2002) 


\section{TABLE 1: The relationship between effectiveness and political economy of aid}

\begin{tabular}{|c|c|c|c|c|}
\hline & $\begin{array}{l}\text { Donors have multiple } \\
\text { objectives }\end{array}$ & $\begin{array}{l}\text { Imperfect information } \\
\text { and broken feedback } \\
\text { loop }\end{array}$ & $\begin{array}{l}\text { Principal agent problems } \\
\text { within aid agencies }\end{array}$ & $\begin{array}{l}\text { Collective action } \\
\text { between aid agencies }\end{array}$ \\
\hline $\begin{array}{l}\text { Aid undermines } \\
\text { accountability }\end{array}$ & $\begin{array}{l}\text { Donors use aid to } \\
\text { promote specific policies } \\
\text { in recipient countries, } \\
\text { undermining domestic } \\
\text { policy space. }\end{array}$ & $\begin{array}{l}\text { Donors impose separate } \\
\text { accountability } \\
\text { mechanisms to monitor } \\
\text { performance }\end{array}$ & & $\begin{array}{l}\text { Aid agencies impose } \\
\text { multiple targets and } \\
\text { conditions on recipient } \\
\text { governments }\end{array}$ \\
\hline $\begin{array}{l}\text { Poverty } \\
\text { reduction is } \\
\text { compromised } \\
\text { by pursuit of } \\
\text { broader } \\
\text { interests }\end{array}$ & $\begin{array}{l}\text { Donors do not spend aid } \\
\text { in the most effective } \\
\text { ways or in the places it } \\
\text { would do most good. }\end{array}$ & $\begin{array}{l}\text { The costs of diverting aid } \\
\text { to other objectives are } \\
\text { not sufficiently well } \\
\text { known. }\end{array}$ & & $\begin{array}{l}\text { Aid agencies compete } \\
\text { with each other for } \\
\text { influence, access to } \\
\text { natural resources, } \\
\text { commercial preferment. }\end{array}$ \\
\hline $\begin{array}{l}\text { Proliferation, } \\
\text { transaction } \\
\text { costs, admin } \\
\text { costs }\end{array}$ & $\begin{array}{l}\text { Donors are spread too } \\
\text { thin - trying to do too } \\
\text { many things in too many } \\
\text { countries for broader } \\
\text { strategic or commercial } \\
\text { reasons. }\end{array}$ & $\begin{array}{l}\text { Transaction and } \\
\text { administration costs are } \\
\text { driven by the need to } \\
\text { monitor inputs in the } \\
\text { absence of ways to } \\
\text { monitor outcomes. }\end{array}$ & $\begin{array}{l}\text { Development staff have } \\
\text { an interest in pursuing } \\
\text { their own interests and } \\
\text { specialisms and resisting } \\
\text { prioritisation or } \\
\text { simplification. }\end{array}$ & $\begin{array}{l}\text { Aid agencies all want to } \\
\text { be represented } \\
\text { everywhere, which leads } \\
\text { to proliferation. }\end{array}$ \\
\hline $\begin{array}{l}\text { Short termism, } \\
\text { lack of } \\
\text { predictability }\end{array}$ & $\begin{array}{l}\text { The loss of effectiveness } \\
\text { from short termism is } \\
\text { outweighed for donors } \\
\text { by other objectives. } \\
\text { Donor decision makers } \\
\text { often have short } \\
\text { (political) time horizons. }\end{array}$ & $\begin{array}{l}\text { Because long term } \\
\text { progress and impact } \\
\text { cannot be monitored, } \\
\text { agencies prefer to be } \\
\text { able to react to events }\end{array}$ & $\begin{array}{l}\text { Development staff are in } \\
\text { demand when they } \\
\text { innovate, design new } \\
\text { programmes, change } \\
\text { decisions. They have no } \\
\text { interest in stability. }\end{array}$ & $\begin{array}{l}\text { Donors who wish to } \\
\text { retain short term } \\
\text { flexibility free ride on the } \\
\text { relative stability provided } \\
\text { by those willing to } \\
\text { eschew it. }\end{array}$ \\
\hline $\begin{array}{l}\text { Lack of focus on } \\
\text { results }\end{array}$ & $\begin{array}{l}\text { If a purpose of giving aid } \\
\text { is to promote image and } \\
\text { relationships, then } \\
\text { donors can make do with } \\
\text { announcements of inputs } \\
\text { and are less interested in } \\
\text { results. }\end{array}$ & $\begin{array}{l}\text { Information costs make it } \\
\text { hard to collect and } \\
\text { evaluate results. }\end{array}$ & $\begin{array}{l}\text { Inputs are easier to } \\
\text { monitor than results. } \\
\text { Staff therefore focus } \\
\text { disproportionately on } \\
\text { inputs, on which they will } \\
\text { be measured, rather than } \\
\text { the results achieved. }\end{array}$ & $\begin{array}{l}\text { Agencies want to } \\
\text { account for their own } \\
\text { contribution, not the } \\
\text { collective impact and } \\
\text { progress. This leads them } \\
\text { to focus on inputs rather } \\
\text { than collective impact. }\end{array}$ \\
\hline
\end{tabular}

41. Table 1 illustrates how the political economy contributes to the shortcomings of aid. It does not follow that removing the problems listed in the columns would be sufficient to address all the problems of aid. But it does suggest that the political economy of aid is a driver of inefficiencies; and that it will therefore take more than good intentions and declarations at international conferences to make progress.

42. Bertin Martens has described the political economy of aid institutions at length (and much of this discussion is informed the analysis in Martens, Mummer, Murrell, Seabright \& Ostrom, 2002; and in Ostrom et al, 2002). Martens argues that measures to make aid work better should pay more attention to institutional economics. He warns, for example, that measures to increase the voice and power of developing countries in the aid partnership may have the unintended consequence of reducing support for aid in donor countries, because it 
disrupts the equilibrium that has been established between the interests of the donors and the interests of the recipient. Martens notes that aid increased during periods of maximum conditionality - such as during the time of the structural adjustment policies promoted by the international financial institutions, and that it declined when the pendulum swung towards ownership by developing countries.

43. At the time of writing in 2009 the Government of Tanzania has become more assertive about the need for a better division of labour between donors, as envisaged in the Paris and Accra declarations on aid effectiveness. This has been greeted with some dismay by donors in Tanzania, some of whom are privately considering either reducing aid, or providing that support through separate projects rather than budget support. The reason is that giving aid is less attractive if the donor has influence over fewer areas of public policy. This is an example of the way that reforms to increase aid effectiveness could undermine political and public support for continuing increases in aid if the reforms simply ignore the politics and institutional priorities.

44. This analysis is at the heart of why this paper argues that reformers should not seek to move away from the political equilibrium, but rather to find ways to change it. The constraints and incentives which determine that equilibrium are not exogenous and fixed: they are, at least in part, endogenous. The incentives which drive aid agency behaviour are a consequence of the institutional environment and technology, and they can be changed by an appropriate combination of well-designed structural changes.

45. Some development agencies aim to work towards a better understanding of the political economy of developing countries, and hope to design interventions that will accelerate reform by influencing that political economy - for example, by strengthening the voice of women or of marginalised communities, or by building a coalition for economic reform strong enough to overcome vested interests. If development agencies believe that they can understand and influence the political economy of foreign nations, they might also invest some of that capacity in understanding how to change the political economy within which they themselves operate.

46. In the next section we consider how the global governance of aid might be improved by greater use of market mechanisms and networked collaboration, in ways that might change the political economy of aid institutions. While we cannot be sure that these measures will work, the analysis above suggests that reform is unlikely to succeed, and may actually do some harm, unless deliberate steps are taken to change the political economy of aid.

\section{PLAN N ING, MARKETS \& NETWORKS IN DEVELOPMENT}

47. In section two we argued that the political economy of aid is an obstacle to improving its effectiveness. Aid agencies exist for good reasons: to mediate between competing interests, to reduce the costs of information asymmetry, and to secure returns to scale. The multiplicity of aid agencies gives rise to collective action problems between them, and principal-agent problems within the delivery chain. 
48. There are many other examples of the need for coordination among multiple actors with diverse motives and interests to achieve a collective good. In almost every field of human endeavour society create systems and institutions to arbitrate among different interests and to coordinate actions to help us to achieve our collective ends. These approaches fall into three broad paradigms: planning, mark ets, and networks. Each has something to offer, and each has shortcomings, as we think about how to improve the international development system.

\section{PLANNING AND REGULATION}

49. O rganising large-scale economic activities by central planning has been out of fashion for the last half a century. Nonetheless almost all smaller organisations often use planning internally: for example, firms often draw up strategic plans and allocate resources by management decisions (sometimes after long committee meetings). Although some larger organisations (including the World Bank) have tried to set up internal markets, with varying degrees of success, most use some form of planning to allocate resources and choose among priorities.

50. Good planning requires decision-makers to have a vast amount of information to make the right decisions. They must know how much it costs to produce every good and service, and how much those goods and services are valued by consumers.

51. Just as there are no completely free markets, in practice planners makes widespread use of complementary market mechanisms. Workers in factories in planned economies are paid a wage to go to work; which they use to buy goods and services in public and private markets. Within firms that use internal planning, market incentives are used to reward success and incentivize behaviours that are beneficial to the organisation.

"E ffective partnerships among donors and recipients are based on the reoognition of national leadership and ownership of development plans ... The goals, targets and commitments of the Millennium D edaration and other internationally agreed development targets can help countries to set short- and medium-term national priorities as the foundation for building partnerships for ex ternal support"

The Monterrey Consensus (2002)

52. The planning paradigm plays a hugely important role in development thinking. The Millennium D evelopment Goals, first articulated by the DAC in 1996, and endorsed by the UN in 2000, set global objectives for aid (OECD D AC, 1996). The DAC Guidelines on Poverty Reduction say,

"D evelopment $œ$-operation will support goals and priorities as set out in national strategies for sustainable poverty reduction, which should be country-driven, participatory, omprehensive and resultsoriented." (OE CD 2001). 
53. The model of development cooperation set out in the Monterrey Consensus, the Paris D eclaration and the Accra Agenda for Action is that the government will produce a nationally "owned" strategy, and that donors should then agree between themselves and with the government which part of that strategy each will support. Important features of the contemporary aid architecture have their roots in the idea of organising around a common, centrally defined plan, such as Poverty Reduction Strategy Papers (PRSPs), Sector Wide Approaches (SWaPs), and Joint Assistance Strategies (JASs).

54. An example of the way that the planning paradigm has been relied upon to coordinate donors is the $2007 \mathrm{EU}$ Code of Conduct for the Division of Labour. Improving the division of labour is potentially an important way to improve the effectiveness of aid, and it has its roots in market economics. Adam Smith identified the division of labour as the main source of improvements in productivity (Smith, 1776):

"T he greatest improvement in the productive powers of labour, and the greater part of the skill, dex terity, and judgment with which it is anywhere directed, or applied, seem to have been the effects of the division of labour."

55. In a market economy, however, the division of labour is the result of individual, uncoordinated decisions in a market, not the outcome of a negotiation. Firms choose which products to produce to make the most profit for the business. If they do this well, they will choose to concentrate on those products which they can do better, because that is where they will make the highest profits. The division of labour is an important determinant of productivity and hence of social value, but it is the decentralized pursuit of profit, not coordination among firms, that brings it about.

56. By contrast, the development community envisages that it will bring about a better division of labour by committee. The EU Code of Conduct commits EU member states to decide among themselves who will do what in each country (EU Council, 2007):

"E U donors will focus their activities on two focal sectors on the basis of their respective comparative advantages. ... E U donors should ensure that at least one $\mathrm{E} \mathrm{U}$ donor is actively involved in each strategic sector considered relevant for poverty reduction. ... E U donors will furthermore seek to limit the number of active donors to a max imum of 3 per sector by 2010."

57. A better division of labour as envisaged in the Accra Agenda for Action may well be a desirable way of improving the effectiveness of aid; but the coordination mechanism envisaged here for bringing it about is that of a planned economy not a market: it is a collective decision among the donors about who will do what, according to where they believe their strengths lie. (This form of collusion to decide which firms would enter which markets would be illegal in the setting of a market economy.) In practice, the process is hampered because donors appear unable to agree their comparative advantage (they all seem to believe they have a comparative advantage in almost everything) and they lack the evidence needed to take such a decision. 
" "T he problem with aid has not been too much ompetition among donors, as conventional wisdom has it, but too little. The decentralized mark et that matches donors and beneficiaries should be the mechanism that coordinates donors. The mark et does not have two different suppliers producing the same output for the same austomer, unlike the frequent duplication in foreign aid, because onoe that customer's demand is satisfied there is no incentive for another supplier to satisfy it again."

William Easterly (2002)

58. Easterly's analogy with competitive markets is not quite accurate, as the developing country's need for additional resources is not "satisfied" by a small number of suppliers; so the "customer" feels obliged to accept aid from every possible supplier, even if it would be preferable to have a smaller number of larger suppliers providing the same total amount of aid. But his central point is correct: in markets it is customer choice, not supplier committees, which implicitly determine the division of labour.

59. The current approach to improving aid effectiveness is rooted in a planning paradigm. The Paris D eclaration calls on developing countries to produce national development strategies, and translate them into operational programmes and annual budgets. D onors are called upon to base their support on these strategies, and use the strategies as the basis of indicators of progress. D eveloping countries commit to establish national frameworks for performance assessment. D onors should "implement, where feasible, common arrangements at country level for planning, funding (eg joint financial arrangements), disbursement, monitoring and reporting to government on donor activities and aid flows." D onors also should work together to harmonize procedures. Partner countries are asked to "establish results oriented reporting and assessment frameworks that monitor progress against key dimensions of the national and sector development strategies". D onors are asked to rely on this results-oriented reporting, and to harmonise their monitoring and reporting requirements.

60. The application of the planning paradigm in aid has come under sustained criticism, notably from Easterly who argues that it relies too much on the role of governments, that it stifles innovation, that it pays too little attention to results, and that it is an inefficient way to allocate resources (Easterly, 2007).

\section{PLANNING AND THE PROBLEMS OF AID}

61. While planning and coordination may help to address some of the collective action problems, they do not solve the problems of imperfect information and lack of feedback, competing objectives, and principal-agent problems. This means that there are significant drawbacks to using planning models as ways of coordinating and improving development cooperation:

a. Planning does not solve problems of multiple, competing objectives. In an archetypal planned economy, the planners have power over firms (usually through the monopoly of state violence). In development, by contrast, the agencies are arms of sovereign governments, and planners have no formal power or effective sanctions to require them to do anything that they do not perceive to be in their interests. In the absence of enforcement 
mechanisms, planning may help to coordinate activities where interests are broadly aligned and complementary, but it does not solve the problem where the objectives of different development actors are competing or in conflict. This means, for example, that donors may be willing to cooperate on joint sector strategies, but there is very little progress on controlling proliferation.

b. The planning framework is especially ineffective in an environment of incomplete information and the broken feedback loop. Effective central planning depends on access to a large amount of information, which makes it particularly ill-suited to the development context in which information is scarce and expensive. There have been efforts to encourage governments to engage citizens more directly in the planning process by calling for "participatory" approaches to developing poverty reduction strategies (PRSPs), but this is a very indirect way of addressing the broken feedback loop, and it has so far not been successful.

c. The principal agent problems are played out through the planning process. D evelopment agency staff participate in the planning meetings, and ensure that their own personal or organisational objectives are satisfied. Poverty reduction strategies become Christmas trees of donor-driven initiatives and priorities. Plans cease to be a mechanism for resource allocation among competing priorities, and operate as baggy narratives that collectively describe the activities of each of the development agencies.

d. Planning does not promote adaptive efficiency. There is nothing in the planning framework to encourage innovation and experiment, to repeat and expand successful programmes or to exit from ineffective approaches and organisations.

62. This analysis suggests that the idea of collaborating to design and implement a common plan is most likely to be productive where donors have broadly shared interests, and where collaboration on the plan can be effectively enforced, either by the developing country government or by some regulatory framework. Without enforcement, planning will not resolve conflicting donor priorities.

\section{PLANNING, EFFECTIVE GOVERNMENT AND THE COUNTRY-LED APPROACH}

63. The country led approach is not the same thing as central planning.

64. The country-led approach places developing countries themselves at the forefront of their development process. It is for the people of developing countries to decide how they want to build their institutions, economy and society. There is considerable evidence that attempts to impose models from outside are unlikely to succeed.

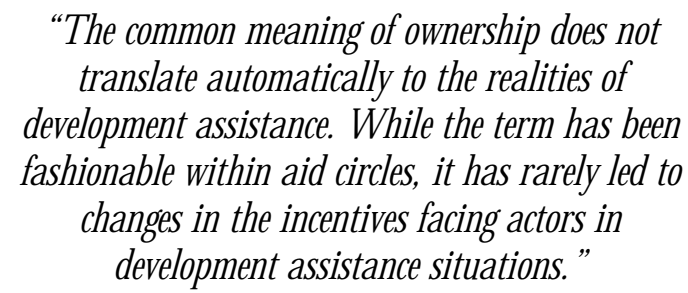

"T he common meaning of ownership does not translate automatically to the realities of development assistanœ. W hile the term has been fashionable within aid circles, it has rarely led to changes in the incentives facing actors in development assistance situations."

O strom et al (2002) Governments have a critical role in articulating and promoting society's values and priorities, and a responsibility to guarantee 
security and human rights. They play a role in shaping and regulating the functioning of markets. In many countries they also have a key role to play in the provision of public services, though the extent of this role varies from one country to another. Aid should support the development of the country's own legitimate and accountable institutions, rather than develop separate, parallel organisations.

65. None of that is a reason for developing countries to be required to introduce and operate top-down, five year strategic plans. In retrospect, the Poverty Reduction Strategy Paper process may have been a well-intentioned imposition from outside, invented by donor bureaucracies needing a planning framework to coordinate their actions. Planning is not a necessary corollary of adhering to the country-led approach, nor is it a necessary condition of supporting the evolution of effective states: as we shall see, markets and networks can be just as effective as planning - possibly more so - in ensuring that developing countries are able to exercise genuine control of their own development.

\section{MARKETS}

66. Markets are an alternative way to coordinate the decentralized actions of many different individuals or organisations with different objectives. Compared to planning, markets are likely to be especially effective in the absence of perfect information.

67. Markets can be an effective way to solve collective action problems - for example, a cap and trade system of carbon emissions is a possible approach to the collective problem of climate change which could create commercial incentives for individual firms to limit their own carbon emissions and so contribute to the collective good.

"It is not from the benevolence of the butcher, the brewer, or the bak er that we ex pect our dinner, but from their regard to their self-love, and never talk to them of our own necessities but of their advantages."

Adam Smith, The Wealth of Nations (1776)

68. In the real world, pure laissez faire markets are rarely the best way to achieve a beneficial outcome. Markets must be framed by institutions which support the operation of the market (eg courts to enforce contracts, a stable currency to facilitate exchange), create markets where none naturally exists (eg intellectual property rights, spectrum rights), ensure that participation in the market is fair (eg financial market regulators, food safety regulations), and to correct market failures such as negative externalities (eg taxes on pollution) or lack of investment in public goods (eg security or R\&D). Within appropriate public policy frameworks of these kinds, however, markets can be an effective way of organising the decentralized actions of multiple stakeholders with different interests.

69. A particular advantage of markets is adaptive efficiency. In some circumstances markets can create an environment that promotes experimentation, and allocates resources to the most successful organisations, while forcing less effective approaches to adapt or die. In a market framework the size and focus of each organisation are the product of evolution rather than design. The long-run benefits of creating a system which promotes innovation, 
adaptation and improvement are likely to far exceed the one-off benefits of improving an existing system to improve its efficiency or its allocation of resources.

70. There have been periodic calls for greater use of market-like mechanisms in aid (e.g. Klein \& Harford, 2005; Easterly, 2002). These have focused on the need for:

a. more innovation and experimentation - for example, Easterly calls for "searchers" in aid (Easterly, 2007);

b. mechanisms by which successful organisations and activities receive more funding, and the unsuccessful are allowed to wither (these often take the form of calls for results-based funding);

c. a better feedback loop by which intended beneficiaries of aid can have more influence over what kind of assistance they receive;

d. greater efficiency through stronger external incentives for delivery organisations, and internal incentives for staff of development agencies;

e. a greater role for the private sector in both giving aid and implementing aid projects.

71. However, nobody has yet articulated a coherent vision of how the aid industry can make more systematic use of the market mechanisms. D espite its provocative title, Klein and Harford's The M ark et for A id does not set out to explain how such a market could work, but rather collects together a series of examples of how market-like mechanisms have been used (Klein \& Harford, 2005). There are some examples of the use of market-like tools. The World Bank has promoted the Global Partnership for O utput Based Aid which uses market contracts with private sector suppliers to provide development outcomes (such as improvements in infrastructure for water and sanitation). The World Bank's development marketplace is a competition for funding to encourage innovation in development. Kiva.org is a person-to-person micro-lending website, which connects lenders directly with borrowers. There are many good examples of the use of vouchers (see Easterly, 2002 for a review of voucher schemes). The idea of Cash on D elivery aid is getting some traction (Birdsall, Savedoff \& Vyborny, 2009). But these remain a relatively small share of total aid - more a curiosity than a new model for aid cooperation.

72. There are two key conceptual challenges which inhibit greater use of markets in development assistance: it is not clear who the consumers are in this market, and there is at present no obvious analogue to the price signal.

\section{WHO IS THE CONSUMER IN THE MARKET FOR AID?}

73. In most markets, the consumer of a good or service is both the purchaser and the intended beneficiary. In the case of aid, the funders are usually taxpayers of the donor country; and decisions are taken on their behalf by the aid agency buying the development services, instructed by the political office-holders leading those organisations. The decisions are 
almost never made by the intended beneficiaries of aid, and there is no cost-effective way for the purchasers to gather information about what services are needed and whether the service has been properly delivered.

74. Market-like mechanisms will only be effective if the interests of decision makers are closely aligned with the interests of the intended beneficiaries. The broken feedback loop in aid is a serious obstacle to this, since (as discussed above) the intended beneficiaries of aid have no political influence over the funders and decision makers.

75. There are two possible approaches to closing this feedback loop, known as short chain acountability and long chain acountability respectively (World Bank, 2004).

76. The "short chain" way to make aid more accountable to the beneficiaries is to give beneficiaries more control over the organisations that deliver services. O ne way to do this is to provide aid directly to the intended beneficiaries - for example, in the form of cash transfers or vouchers. $G$ iving choice to the intended beneficiaries is one way to make services more directly accountable. There is growing evidence that this can work well, though there are some circumstances (such as for the provision of public goods) for which it is unlikely to be suitable.

72. The "long chain" way to make aid more accountable is to give much greater emphasis to transparency, community engagement, measurement of results and feedback through the political system. Civil society organisations and politicians in donor and recipient countries should have access to information about how aid has been spent and what the impact has been. This would enable them to put pressure on policy-makers in both donor countries and recipient countries to improve the effectiveness of how aid is used. The Twaweza project in Tanzania is an example of a framework for making service delivery more transparent, so increasing political pressure on national and local political office holders to improve services. The most important accountability relationship is between the government of a developing country and its citizens; but to the extent that important decisions are in practice taken by foreign donors, some mechanism is needed to link accountability for those decisions to the impact on beneficiaries.

72. The reality is that the purchaser in a market for aid is nearly always the taxpayer or funder, not the intended beneficiary. Funders provide money to, and expect results from, providers, who include donor governments, aid agencies, recipient governments, service delivery organisations, civil society organisations and private sector firms. We might prefer that more power should rest with the intended beneficiaries, or at least their governments or representatives, but we should not base policy on wishful thinking. O nce we accept that the consumer in this market is the person paying for poverty reduction, we can think more rigorously about the information and incentives that need to be put in place so that these consumers will enter into effective agreements with the providers to deliver poverty reduction which meets the needs of the intended beneficiaries. 


\section{THE PRICE MECHANISM, EXPLICIT CONTRACTS AND “UNBUNDLING” AID}

72. The second conceptual problem is that there is no obvious analogue to price. Markets work by simplifying large amounts of information about preferences, costs, and effectiveness into a simple, transparent price signal. In the aid system, there are rarely explicit measures of the price of each output which would provide signals to producers and consumers.

72. One way to introduce a more explicit price signal into aid would be to create more explicit contracts for development services to expose prices and performance. Under current arrangements, there is normally vertical integration between the purchaser and the organisation they employ to provide development services. Once a government decides to give aid to a particular country, their own staff are typically asked to design and manage a suitable programme. The implementation will usually be contracted out, but the design and appraisal, and subsequent evaluation, is all internal. There may be internal discussion about the priorities for how money should be used and the possible impact, but this is rarely codified into a price and a set of expected outputs against which performance can be monitored, both internally and externally. One way to establish a price signal would be to make these choices explicit and transparent, and then to evaluate performance against results more rigorously. As well as making clear the cost of different outputs, explicit contracts would also have the benefit of increasing public confidence in the aid programme.

73. Once spending is explicitly and transparently linked to results, funders could go further by unbundling funding from delivery. This would mean opening up these contracts to competition among a range of aid delivery agencies, both public and private sector. Competition among service providers could lead to greater specialisation and division of labour, incentives to define and measure results, and there might be dynamic improvements as organisations were forced to specialise more, improve their effectiveness, and produce credible evidence of results.

74. There have been many examples around the word of seeking to improve public services by separating the purchaser from the provider and creating more explicit contracts for delivery. This is a common idea in the so-called the New Public Management approach to public service reform. Some of the best known examples have been in health care and social care, for example in the UK, Australia and New Zealand. Some of these failed; others have worked well, especially where they have succeeded in focusing the attention of policy-makers on outcomes rather than inputs and process. D onors wanting to move in this direction would need to pay attention to the lessons of these experiences. Paradoxically the development system has mimicked some of the less successful features of these reforms, especially the imposition of top-down targets (Bevan \& Hood, 2006), but it has not pursued the more successful components of choice and competition (Cooper et al, 2009). It would be prudent for donors to begin with a shadow internal market to establish how explicit contracts can work before opening up to external competition.

75. Such unbundling of funding from aid management, and a more explicit focus on results, need not reward short-term service delivery at the expense of long-term institutional capacity building. If a funder attaches importance to building institutional capacity this can be specified in the invitation to tender, and it is then up to the service providers to show how 
their approach will build capacity as well as delivering services, and how this increase in capacity will be demonstrated. Arguments about the respective merits of different aid modalities and different approaches would be settled in a market-place of evidence and results rather than by political negotiation.

\section{MEASURING AND PAYING ATTENTION TO RESULTS IN A MARKET}

72. Experience from other sectors using explicit markets, and within the development sector the experience of challenge funds and other competition for funds, suggests that there will be two key challenges for efforts to create more explicit contracts for the delivery of aid services:

a. finding ways to articulate results in a way which can be rigorously defined and monitored and compared across different activities;

b. creating incentives for decision-makers to focus primarily on results, and the impact on intended beneficiaries, as opposed to making choices based on other institutional objectives.

73. Because development results are often not sufficiently rigorously defined and monitored, there is a tendency for extravagant claims to be made about what aid can achieve. Alex De Waal (1997) has written of a 'Humanitarian G resham's Law', in which aid agencies that are willing to make exaggerated claims about what they can achieve will secure more of the funding, and so drive other, more honest agencies out of business. Similarly, Kremer \& Miguel (2004) have observed:

"O ne possibility is that aid agencies are stuck in a rat raœ with each other for limited donor funds, and try to outdo each other in ex travagant claims about what can be achieved ... Claims about spectacular project "bang for the buck" typically remain unchallenged since aid agencies are not directly acoountable to program beneficiaries through either political mechanisms (e.g., democratic elections) or the mark et mechanism, and rigorous program evaluations are rare."

74. A market for aid could be an opportunity to reverse the existing incentives to overstate results, if it can create competition among service providers not only on the basis of what they claim they will achieve, but how rigorously they are able to demonstrate success. If the market encourages innovation among service providers to come up with better ways to demonstrate results, in the expectation that they will win more contracts as a result of doing so, the effect may be that rigorous measurement of results drives out exaggerated and spurious claims, reversing the current trend.

75. More explicit measures of results will only lead to better decisions if the policy-makers are able attach sufficient importance to the impact on beneficiaries, rather than other institutional objectives. The market alone cannot create those incentives. It seems likely that complementary network-like mechanisms, especially greater transparency, will play an important role, by creating stronger accountability of decision makers. (This is an example of how the "collaborative markets" proposal differs from a pure market mechanism: 
complementary measures from the paradigms of markets, networks and regulation are needed.)

\section{POSSIBLE BENEFITS OF A MARKET IN AID}

72. If aid could work more like a market in a way that creates incentives for purchasers to focus on results and the interests of intended beneficiaries, and if the implicit price of aid programmes and results can be made explicit, then market-like approaches could help to provide solutions for three of the key political economy challenges facing the aid system:

a. principal-agent problems in the aid delivery chain: greater use of explicit contracting would help to align incentives of aid agencies and contractors with the intentions of their funders. The World Bank's output-based aid programme is an example of this;

b. incomplete information: markets can reduce information needs by decentralizing decision making; for example, Cash on Delivery Aid (in which donors make payments based on the achievement of particular outputs or outcomes) require the donors to know much less about the specific circumstances of a country, and so help to overcome asymmetric information (Birdsall, Savedoff \& Vyborny, 2009). Empowering the intended beneficiaries (eg through voucher schemes) also bypasses the need for donors to monitor behaviour and processes (Easterly, 2002). An explicit market would increase incentives for aid agencies to collect and report information about impact.

c. collective action: markets are often an effective way to coordinate the actions of multiple decision makers with diverse and competing interests, but only if the market operates within institutions that enforce the rules of the market, and ensure that decision-makers bear the consequences of their decisions, for example by imposing taxes on negative spill-overs (such as proliferation) and subsidizing positive spill-overs (such as rigorous evaluation).

73. When they work well, markets can be an effective way to decentralize decision making and to reduce the power of providers. Markets for aid can support the country led approach, in which the citizens of developing countries are able to have a bigger say over their own path to development, especially if (as seems likely) aid will prove to be more effective when it is under genuine control of the recipients. By contrast, the development system has not yet found an effective way to reconcile the country led approach with its reliance on the planning paradigm which dominates donor thinking about how to coordinate their activities. Promoting participation by encouraging beneficiaries to draw up national plans has not had the desired effect, not least because the process was rapidly taken over by donors, who issued thousand-page handbooks on what the national plans should contain, and in some cases drafted the plan themselves. More effective use of markets could be a way to empower the governments and citizens of developing countries to exercise real choice over the nature of the development assistance they receive. 


\section{NETWORKS}

72. There are more and more examples of collective action through networks as distinct from mark ets or planning. Networks draw on the possibilities offered by social production or crowd sourcing, harnessing the collective wisdom of large numbers of people with diverse experiences and perspectives (Benkler, 2006; Suriowecki, 2004).

73. Wikipedia is an encyclopaedia written and maintained by volunteers, with no central planning and no monetary remuneration. Newspapers face competition from "citizen journalists" using blogs, podcasts and twitter to share news and comment (Gilmoor, 2004). The wisdom of crowds has been used to identify targets for prospecting for minerals and for pharmaceutical compounds (Suriowecki, 2004). Free software is developed by unpaid collaborators around the world, producing stable and secure software (eg Apache which is used by two-thirds of the world's web servers; and the Linux operating system). People who buy books online use automatic recommendations based on the previous purchasing choices of other people; and booking hotels has been made easier by online reviews by previous guests. These successes suggest that networks can be used to engage a larger number of people in a common cause motivated by non-market motives such as a desire to contribute to a collective good, or for recognition or attention (Tapscott \& Williams, 2006).

74. Networked organisations have so far had most impact in applications that involve sharing knowledge and ideas, particularly where these can benefit from tapping the collective wisdom and experience of diverse individuals. Social production is especially well suited to problems that can be divided into many simple and discrete tasks, such as the production of open-source software or translating scanned books into digital format. In May 2009, for example, Google Maps added detailed and accurate road maps of 64 countries, predominantly in Africa, where official geographical data were scarce, using data contributed by users through the G oogle Map Maker tool. ${ }^{5}$ Weather Underground assembles meteorological data from thousands of people who purchase and install home weather stations.

75. In contrast to the planning paradigm, which is centralized, regulated, comprehensive and focused on the role of government, the network paradigm is decentralized, voluntary, issuespecific, and can be both public and private. But networks are not simply voluntary free-foralls: they are built on a shared infrastructure, technical and information standards, codes of conduct and social expectations.

72. There are characteristics of the development community that suggest that it would embrace the network paradigm to improve its coordination (Shafik, 2009). There are many aid agencies with diverse strengths but with a largely common set of goals; to a large extent they should collaborate, not compete, to achieve them together. The networked model of

5 http:/ / google-africa.blogspot.com/ 2009/ 06/ new-african-countries-live-on-google.html 
cooperation appears to be consistent with many of the values of people working in development, many of whom see themselves contributing to a greater good, and who are motivated by non-financial considerations.

73. Networks have much to contribute to reducing information costs and asymmetries by allowing all actors to share their knowledge and experiences. They can provide a platform to help repair the broken feedback loop by enabling the intended beneficiaries of aid to report their experiences and express their priorities to decision makers in their own governments and in donor countries.

74. The network paradigm may also contribute to reducing principal-agent problems by significantly improving the transparency and accountability of development agencies themselves, and organisations that deliver aid for them. The publication of expenses claims by UK Members of Parliament during 2009 provides a topical example of how greater transparency can reduce the principal-agent problem. In this case, increased access to information has significantly changed the incentives facing decision-makers, aligning their interests more closely with those of their employers.

75. Networks are well suited to solving collective action problems where objectives are shared but coordination is constrained by information costs (for example, coordinating diverse but complementary interventions among many actors). They are much less likely to be effective at coordinating the activities of diverse actors with competing priorities and contradictory objectives, because participation is voluntary and networks typically do not provide mechanisms for conflict resolution or to enforce decisions.

" "G iven the absenœ of mark et forces or enforcable regulation, these trends in the aid industry place a higher premium on transparency, benchmarking and independent evaluation."

Minouche Shafik (2009)

75. The evolution of the Working Party on Aid Effectiveness as a network of donors and recipient countries illustrates some of the benefits and some of the limitations of the network paradigm. It has been very helpful to have a group of countries working together to agree an agenda for improving aid effectiveness. Participants have learned from each other and peer pressure has helped to promote change. There is considerable agreement on the agenda for how the aid system should change. But in the end, the Working Party cannot impose its decisions on anyone, so that its agreements tend to be either voluntary or vacuous.

76. The take-up of the network paradigm in development has so far been modest. It has been applied most obviously to support knowledge-sharing among development professionals. Networked cooperation underpins many communities of practice such as PovNet and GovNet. In 1996 the then President of the World Bank announced the Bank's aspiration to become a (possibly the) Knowledge Bank, and it established the D evelopment Gateway as a portal to development information (Cohen \& Laporte, 2004). The 
GlobalGiving.com website, established by former World Bank staff, aims to link individual donors directly to worthy causes.

77. Network approaches may offer effective ways to strengthen the accountability chain and help to close the feedback loop by providing more accessible information about what is working. The Center for Effective Philanthropy seeks to improve information about and collective monitoring of philanthropic giving. ${ }^{6}$ Keystone Accountability ${ }^{7}$ and ALINe are working to improve the feedback loop between intended beneficiaries and decision-makers. ${ }^{8}$ The Humanitarian Accountability Partnership (HAP international) seeks to create new organisational incentives (in the form of auditable standards) for agencies to be accountable to their intended beneficiaries. ${ }^{9}$

78. Bureaucracies have however been slow to embrace the more disruptive facets of the network paradigm, especially the ideas of non-hierarchical, open collaboration and social production. When the D evelopment $\mathrm{G}$ ateway was conceived within the World Bank, it was described as a way to collect and organise the world's knowledge. In effect, it tried to reproduce electronically the existing power structures in the creation and dissemination of knowledge. Information was to be gathered from experts (whose views were therefore consistent with the dominant discourse) and then centrally managed, approved and quality controlled. There was originally no plan to allow users to contribute and validate information themselves, or to use social networking tools to determine what was interesting or important. (All this has subsequently changed, now that the D evelopment $\mathrm{G}$ ateway is independent of the World Bank.) Contrast this to G oogle, which ranks search results according to an algorithm based on the number of other websites that link to the

"T he best collective decisions are the product of disagreement and ontest, not consensus or compromise. ... The best way for a group to be smart is for each person in it to think and act as independently as possible." "

James Surowiecki, Wisdom of Crowds (2004) page - that is, measuring importance according to the wisdom of the crowd rather than by central quality control. Wikipedia has no panel of experts enforcing quality control. There have been few examples in development so far of using networks and the wisdom of crowds to challenge existing power relationships or dominant narratives.

6 http:/ / www.effectivephilanthropy.org/

7 http:/ / www.keystoneaccountability.org/ ;

$8 \mathrm{http}: /$ / ww.alineplanning.org ALINe is a collaboration by the Institute of Development Studies, Keystone Accountability and the Bill \& Melinda $\mathrm{G}$ ates Foundation on new practices for monitoring \& evaluation in agricultural development

9 www.hapinternational.org 


\section{HOW NETWORKS MIGHT IMPROVE AID}

72. This analysis suggests that the network paradigm can make a significant contribution to overcoming the political economy problems of aid, especially as a complement to market mechanisms:

a. collaborative mechanisms to gather information, especially encouraging social production and crowd sourcing, could help to repair the broken feedback loop. By reducing the costs of gathering and sharing information, it may be possible to create stronger incentives for decision-makers to respond to the interests and needs of the intended beneficiaries;

b. to the extent that economies of scale in aid reflect the costs of fundraising, gathering information and knowledge, and monitoring performance, networks can reduce these costs and so reduce the diseconomies of scale for small and innovative providers;

c. accessible information reduces monitoring costs within aid agencies and so reduces the principal-agent problem; publication of information about activities empowers an army of "armchair auditors" to track and enforce performance;

d. the cost of coordinating among agencies can be reduced by cost-effective information sharing, and it is easier to create and enforce incentives to reduce negative spill-overs or encourage positive externalities.

\section{OVERVIEW}

72. The political economy of aid is such that neither planning, nor markets, nor networks alone can overcome all the challenges. But this analysis does suggest that a well-judged and deliberate combination of these approaches might work. For example, markets in aid are not likely to work well in the absence of good information from beneficiaries about impact; this is a problem that a complementary network approach could go some way to address. 
TABLE 2: RELATIONSHIP BETWEEN POLITICAL ECONOMY \& MODES OF COLLABORATION

\begin{tabular}{|l|l|l|l|}
\hline & \multicolumn{3}{|c|}{ Modes of collaboration } \\
\hline Problem: & \multicolumn{1}{|c|}{ Planning } & \multicolumn{1}{c|}{ Markets } & \multicolumn{1}{c|}{ Networks } \\
\hline $\begin{array}{l}\text { Imperfect } \\
\text { information and } \\
\text { broken feedback }\end{array}$ & No & Partly & Yes \\
\hline $\begin{array}{l}\text { Multiple, competing } \\
\text { objectives }\end{array}$ & No & $\begin{array}{l}\text { Partly - but only if } \\
\text { incentives can be } \\
\text { enforced. }\end{array}$ & No \\
\hline $\begin{array}{l}\text { Principal agent } \\
\text { problems }\end{array}$ & No & $\begin{array}{l}\text { Yes - through explicit } \\
\text { contracting. }\end{array}$ & $\begin{array}{l}\text { Yes - by increasing } \\
\text { transparency and } \\
\text { accountability }\end{array}$ \\
\hline Collective action & $\begin{array}{l}\text { Yes - where interests are } \\
\text { broadly aligned or if } \\
\text { decisions can be } \\
\text { enforced }\end{array}$ & $\begin{array}{l}\text { Partly - but only if } \\
\text { market incentives can be } \\
\text { enforced }\end{array}$ & $\begin{array}{l}\text { Partly - but only where } \\
\text { interests are broadly } \\
\text { aligned }\end{array}$ \\
\hline
\end{tabular}

\section{A COLLABORATIVE MARKET FOR AID}

77. To persuade policy-makers, aid agencies and the public to make big steps on a road to reform, we need compelling vision of the destination towards which we are moving. To assure ourselves that such a vision is realistic, we need to understand how it will be compatible with the institutional and political realities of the aid system.

78. It is an oddity of the Paris and Accra agendas for improving aid effectiveness that it is very difficult to describe what the end-point of the reforms is intended to be. As Andrew Rogerson observed:

"Suppose the Paris agenda proved a complete success, in that preferences of donors and recipients were fully aligned, complete trust and transparency reigned, national systems were systematically reliable, and relied upon, and costs of verification by donors became negligible.... In this state of the world, there is no need for any aid agencies to provide mediation between donor and recipient constituency preferenoes. Direct budget transfers between the two treasuries - as they now ocour between the donors and, say, their own regional governments - would suffioe. ... This scenario illustrates how the Paris agenda effectively ask s aid agencies to work ever more diligently towards their own demise." (R ogerson, 2005)

79. This scenario is implausible because donors and recipients do not have the same objectives, and so their preferences are not fully aligned. The Paris and Accra agendas urge donors to move nonetheless towards a world in which aid agencies eschew the ability to mediate these different objectives. This would not be a sustainable equilibrium. The logical 
destination of the Paris and Accra reform agenda makes sense only if we ignore the reasons why donors have bilateral aid programmes in the first place.

80. If the aid system reflects an equilibrium that balances the interests of donors and recipients, then reforms will be sustainable if they shift the equilibrium. Efforts simply to move away from the equilibrium will not succeed for long, if at all.

81. This section of the paper proposes a vision for the aid system, here called a "collaborative market". The collaborative market draws on the different strengths of the planning, markets and networks paradigms to create an institutional environment for the aid system which promotes evolution towards greater effectiveness. The principles which could promote the evolution of a more effective aid system are:

a. creating explicit and transparent contracts for aid delivery, setting out what will be achieved, at what price, and how the results will be demonstrated. The aim would be to create incentives for more credible and comparable measures of results, and to establish a clearer price signal. This could lead to unbundling funding from delivery to create open and competitive markets for the delivery of aid services, improving incentives for efficient choice of instruments and implementing agencies.

b. investment in a significant improvement in the transparency and accountability of development cooperation, providing open and accessible information to enable aid to be traced from funder to intended beneficiary and increasing the accountability of aid agencies and governments to the intended beneficiaries;

c. repairing the broken feedback loop so that the intended beneficiaries of aid can provide information about their experiences, in ways that are accessible to the funders and purchasers of development services. The challenge is to make this happen in a way which enables the beneficiaries to have real influence on government and donor decisions;

d. collective agreement on a market infrastructure to create explicit and competitive markets for development services, to ensure that decision-makers bear the full costs of their decisions by imposing taxes on negative spill-overs and subsidising positive spill-overs, with an accompanying regulatory and enforcement regime.

82. These changes do not add up to a new blueprint for the aid architecture: they are intended instead to promote evolution of the aid system. Evolution is presently inhibited by the instinct of policy-makers to fall back on planning (indeed, the commonly used metaphor of architecture reinforces the notion that the system should be planned). If we want a system that evolves over time, we need to look to markets and networks to promote variation and selection.

83. Taken together, these proposals for a collaborative market aim to change the political economy of aid. They would address the challenge of incomplete information and the broken feedback loop, drawing on the network paradigm of transparency, collaboration and social production. They would address principal agent problems through greater 
transparency and accountability, and by changing incentives through explicit contracts. They would bring the diverse objectives of funders more closely into line with the needs and priorities of the intended beneficiaries of aid, and makes it harder for aid agencies to set those interests aside in the pursuit of broader and conflicting goals. They would create a platform for collective action based on incentives, decentralized decision-making and accountability, rather than statements of good intent which contradict the underlying institutional incentives.

84. In section one we identified five themes that describe the problems of aid. This paper does not claim that a collaborative market would eliminate these problems altogether. Nor does it claim that any particular measures are necessary or sufficient to reform aid. The claim is more modest: that a combination of measures drawn from the realms of markets and networks, within a collectively agreed regulatory framework, might create incentives for better allocation of aid and more effective choice of instruments; might encourage a better balance between flexibility and predictability; might lead to less focus on inputs and more on results; and might open up policy space in developing countries and increase the accountability of developing countries to their own citizens.

85. In Table 3 below, we describe how the components of collaborative markets might help to address the problems listed in section 1. 
TABLE 3: HOW COLLABORATIVE MARKETS MIGHT ADDRESS THE PROBLEMS OF AID

\begin{tabular}{|c|c|c|c|c|}
\hline & $\begin{array}{l}\text { Explicit contracts } \\
\text { and unbundling }\end{array}$ & $\begin{array}{l}\text { Transparency \& } \\
\text { accountability }\end{array}$ & $\begin{array}{l}\text { Better information } \\
\text { \& feedback }\end{array}$ & $\begin{array}{l}\text { Regulation of } \\
\text { market } \\
\text { infrastructure }\end{array}$ \\
\hline $\begin{array}{l}\text { Aid has negative } \\
\text { impact on } \\
\text { institutions \& } \\
\text { accountability }\end{array}$ & & $\begin{array}{l}\text { Helps citizens to } \\
\text { hold institutions } \\
\text { accountabile. }\end{array}$ & $\begin{array}{l}\text { Feedback from } \\
\text { beneficiaries } \\
\text { increases } \\
\text { accountability of } \\
\text { service delivery }\end{array}$ & $\begin{array}{l}\text { Negative effects } \\
\text { (eg poaching staff) } \\
\text { taxed }\end{array}$ \\
\hline $\begin{array}{l}\text { Donors pursue } \\
\text { broader interests }\end{array}$ & $\begin{array}{l}\text { Contracts make it } \\
\text { less easy for } \\
\text { donors to pursue } \\
\text { non-poverty } \\
\text { objectives }\end{array}$ & & $\begin{array}{l}\text { Greater } \\
\text { beneficiary } \\
\text { influence shifts } \\
\text { power from } \\
\text { donors }\end{array}$ & $\begin{array}{l}\text { Market regulations } \\
\text { enable collective } \\
\text { decisions (eg } \\
\text { untying) }\end{array}$ \\
\hline $\begin{array}{l}\text { Proliferation and } \\
\text { transactions costs }\end{array}$ & $\begin{array}{l}\text { Market-led } \\
\text { division of labour } \\
\text { reduces } \\
\text { transactions costs }\end{array}$ & & & $\begin{array}{l}\text { Market } \\
\text { externalities taxed }\end{array}$ \\
\hline $\begin{array}{l}\text { Short termism and } \\
\text { unpredictability }\end{array}$ & $\begin{array}{l}\text { Costs of } \\
\text { unpredictability } \\
\text { made explicit }\end{array}$ & $\begin{array}{l}\text { Greater } \\
\text { transparency } \\
\text { reduces } \\
\text { unpredictability }\end{array}$ & & \\
\hline $\begin{array}{l}\text { Insufficient focus } \\
\text { on results \& } \\
\text { learning }\end{array}$ & $\begin{array}{l}\text { Competition to } \\
\text { find ways to } \\
\text { measure results }\end{array}$ & $\begin{array}{l}\text { Greater } \\
\text { transparency } \\
\text { improve scope for } \\
\text { learning }\end{array}$ & $\begin{array}{l}\text { More information } \\
\text { increases learning }\end{array}$ & $\begin{array}{l}\text { Subsidies for } \\
\text { evaluation (a } \\
\text { positive } \\
\text { externality) }\end{array}$ \\
\hline
\end{tabular}

\section{WHY MIGHT DONORS IMPLEMENT THESE REFORMS?}

86. Given that donor agencies are constrained by their political and institutional contexts from taking individual decisions that would make aid more effective, why would they be any more likely to implement a set of institutional reforms that would impose such changes on them?

87. A possible answer to this lies in the economic theory of timeinonsistency, which recognizes that a series of rational short-run decisions may not lead to the long-run results to which the decision-maker aspires. A good example of this in public policy is that many countries have chosen to establish an independent central bank with control of day-to-day decisions on monetary policy. It is in the long-run interests of a government to promote low inflation and macroeconomic stability, even though in the short run it may be attractive to relax monetary policy, especially as an election approaches. By eschewing the ability to make short-run changes in interest rates, a government can achieve better results. G overnments 
are willing to put in place institutional structures that promote their long-term interests, knowing that this will constrain their room for manoeuvre in the short run. O dysseus had his sailors tie his hands behind the mast of his ship so that he could hear the voices of the Sirens and yet resist the temptation to sail his ship into the rocks.

88. By analogy, many governments understand that it is in their long-run interest to promote economic progress in developing countries. In the short run, however, it is tempting to provide aid which promotes a particular commercial or strategic interest, or which responds to short-term political pressures at the expense of more predictable and effective aid. By establishing a collaborative market, donors would be choosing to adopt an institutional framework that ties their hands, limiting their short-term discretion to respond to short-term political pressures but increasing the long-term effectiveness of aid.

89. A further reason that donors might implement measures to bring about collaborative markets is that they have a collective action problem. A D utch auction of aid promises from donors to curry favour with developing countries is not in the interests of individual donors, but the system lacks a collective mechanism to prevent it. (Two good precedents for this are the agreement among members of the OECD to avoid competition to provide export credits, and the European Community rules on state aids to businesses.)

90. Putting in place a collaborative market would require some collective decision making by donors and developing country partners. But this type of collective action, to agree new rules of the game and appropriate enforcement mechanisms, is a much more achievable goal than try to coordinate each specific intervention at country level.

91. A third and final reason why donors might implement measures like this is that they are individually politically attractive. There is political resonance in ideas such as greater transparency, more explicit links between funding and results, and greater voice for the intended beneficiaries of aid. While these measures may, in the long run, lead to shifts in the political equilibrium that underpins the aid system, they may be attractive to myopic decision-makers in the short run.

92. For these three reasons - time inconsistency, collective action and political advantage - donors might be willing to implement the measures needed for a collaborative market, in a way that they have not been willing in practice to implement their commitments to improve aid within the current institutional framework.

\section{SPECIFIC MEASURES TOWARDS A COLLABORATIVE MARKET}

93. The main conclusion of this paper is that sustainable improvements in the aid system can only be brought about by reforms that address the political economy of aid and which create an environment in which evolution is possible. Section four proposed principles of collaborative markets - more explicit contracts, greater transparency, more feedback from 
intended beneficiaries, and tougher regulation - which are desirable in their own right and which, taken together, might help to reshape the political economy of aid and encourage evolution of a better institutional ecosystem.

94. We set out below a number of specific measures which could contribute to improved aid effectiveness and to the emergence of a collaborative market. This list of measures is not intended to be the main conclusion of the paper; it is more of a footnote to provide realworld illustrations of how a collaborative market might work.

95. This paper does not provide any analysis of the advantages and disadvantages of these measures. Nor does it attempt to provide any argument or evidence that these measures are each neoessary to make aid more effective. Nor does it provide any argument or evidence that these measures, taken together, would be sufficient. This menu of measures is intended to provoke discussion, and to make the idea of a collaborative market more tangible.

96. Network-like measures as part of a collaborative market might include the following.

a. Donors could design and implement an international decentralized mechanism for sharing aid information, through which detailed information about the activities of aid agencies - including government donors, international organisations and NG Os, can be accessed easily and cheaply. On such a virtual platform, new and innovative tools can be created to enable aid can be traced from the original donor to the final beneficiary; to reduce the costs of coordination, and to increase accountability of donors, recipient governments and implementing agencies, and so make aid more effective. $^{10}$

b. Donors could invest in much more in independent mechanisms for independent, rigorous, transparent, comparable, useful evaluation of aid interventions (which are a public good); these evaluations should focus not only on the process by which aid has been provided but also on the impact that has been achieved. International mechanisms would be more independent, provide more learning across aid agencies, and allow aid agencies to reduce the cost of their own, in-house evaluation functions which tend to duplicate each other and which are not sufficiently independent of their parent institution. The International Initiative for Impact E valuation (3IE) is a good step in the right direction (Banerjee et al, 2007; D uflo, Glennerster \& Kremer, 2008).

c. Top-down evaluations by aid agencies are not enough. D onors and govemments could invest in mechanisms for beneficiaries to provide feedback about the services they receive, through access to information, and support for local civil

\footnotetext{
10 The International Aid Transparency Initiative may be a step in the right direction. See http:/ / www.aidtransparency.net
} 
society organisations. Governments should be accountable to their citizens; and donors should be accountable for the decisions they take. A good example of this is Twaweza in Tanzania, which enables citizens to gather and share information about public services. As well as top-down evaluations, donors could look for other ways to increase the availability of independent, credible data on agency performance. (A good example is the Humanitarian Response Index.) Closing the feedback loop requires that citizens in donor countries and recipient countries are able to see how aid money is being used, and what impact it is having on the intended beneficiaries. The aim should be to create political pressure in donor countries for more effective aid, and in recipient countries for more effective delivery.

d. There could be greater investment in social network, online communities and knowledge sharing platforms, and more willingness to break out of hierarchical and controlled structures of knowledge-sharing and communication. Staff of donor agencies could be encouraged to participate actively.

e. Prediction markets could be used to synthesize and expose implicit knowledge (Hanson et al, 2008). For example, instead of using backward-looking measures of governance, aid allocations could be predicated on forward-looking measures based on traded instruments.

97. In addition, donors could consider complementary market-like measures.

a. As an immediate first step, aid could be completely untied - that is, contracts would not be restricted to individuals or organisations from a donor country.

b. Donor countries could move to explicit contracts for delivery of aid programmes. At first such agreements might be between different parts of a single aid agency which set out explicit, measurable indicators of performance, and the corresponding price; they should be publicly available; and they should be rigorously and transparently monitored. This would create a more transparent price signal and greater emphasis on results, and it would increase public confidence in the way aid funds are used. (In the case of the UK, such contracts might be considered a way of disaggregating the Public Service Agreement into a series of more specific, quantified contracts.)

c. Once explicit contracts are in place and working well, donors could consider unbundling responsibility for funding aid programmes from design, implementation and evaluation by creating open and contestable markets for delivering services. The tenders, the resulting contracts, and the subsequent performance of delivery agents, would be publicly and transparently available. Exit by ineffective organisations would be a consequence, rather than a politically difficult decision. Unbundling is a much more far-reaching proposal than adding a "challenge fund" to existing programmes: it means challenging the monopoly provision of advice and services to aid agency headquarters by embassies and country programmes. 
d. Donors could establish and use online procurement mechanisms for the supply of development services (eg technical assistance, consulting, project management, procurement etc) to facilitate entry, innovation and exit from the market. For example a market for technical assistance similar to "eBay" would enable developing countries to set out their requirements, enabling a bigger variety of providers to bid according to the terms of reference. Service providers would able to earn (or lose) reputation based on feedback from previous clients provided through the online system. Reports and analysis from such technical assistance would all be shared online. Such a system should explicitly encourage the emergence of developingcountry based suppliers which can take advantage of a lower cost base, local knowledge and returns to scale.

e. D onors could focus on results rather than inputs. There are many possible ways to do this, such as cash on delivery aid (Birdsall, Savedoff \& Vyborny, 2009), outputbased-aid (World Bank, 2006), or vouchers; these mechanisms have the potential to increase the focus on results, improve accountability to beneficiaries, and create incentives for efficient delivery. Linking aid to results could also reduce transactions costs (because inputs and processes do not have to be prescribed and monitored), reduce the impact of information asymmetries, and promote ownership by developing countries. Linking aid to results could promote institutional capacity in developing countries by enabling them to develop their own systems to achieve their goals, rather than depending on parallel systems and processes established by donors.

f. Donors could maintain performance funds and challenge funds to promote innovation; aid agencies have not had sufficient reason to invest in innovative ideas ("not invented here") nor have they provided the additional funding needed to ensure that new approaches can be tested rigorously and expanded if successful.

g. Funding for intemational organisations could be linked to results so that the most effective bilateral and multilateral organisations receive more money over time. Unbundling funding from delivery would contribute to this. To the extent that organisations are given central funding, donors could develop a common framework for identifying and measuring outputs; the existing mechanisms for this (such as MOPAN) are insufficiently rigorous in measuring impact and cost effectiveness, rather than judging processes and aspirations. Donors should avoid imposing a higher standard of measurement and accountability on multilateral organisations than on their own bilateral organisations, which could be similarly required to demonstrate their effectiveness to secure access to funds.

98. D onors could also take a number of measures to improve collective action and an effective regulatory framework.

a. Donors could invest time, money and political capacity in the development and enforcement of information and knowledge sharing standards (for aid information, measurement of outputs, standardised indicators, independent and transparent impact evaluation etc) to increase accountability and transparency, and create stronger incentives for improved performance. This is analogous to the need 
for common accounting definitions to enable investors to judge firms, buttressed by an effective audit and regulatory function.

b. There could be centrally determined disincentives for negative spill-overs such as proliferation, hiring skilled staff, or creating parallel systems. For example, each delivery organisation might be required to pay a lump-sum entrance fee (perhaps $\$ 5 \mathrm{~m}$ a year) for each sector for each country in which it operates (so encouraging greater concentration). There might be a tax on each donor mission, project implementation unit, or on each qualified local national employed by a donor. "Cap and trade" would be another way to create incentives against negative spill-overs: for example, developing countries might cap the number of donor missions they are willing to receive each year, and then auction the permits.

c. There could be a stronger presumption of working through multilateral rather than bilateral organisations. Multilateral organisations secure returns to scale, are less likely to be swayed by short-term political pressures, and reduce the transactions costs for recipient countries (Milner, 2004). Greater transparency of funding decisions may help to overcome political pressures to proliferate multilaterals rather than channel more money through the best performing existing organisations.

d. There could be explicit subsidy of development industry public goods: for example, the revenues from the taxation of negative externalities could be used to pay for public goods in the development industry: effective networks of local civil society and research organisations; rigorous independent evaluation; the administrative costs of knowledge sharing networks; or the salary and support for a respected, independent, "aid ombudsman" in each recipient country.

e. A market framework could be supported by binding regulatory agreements. This would be an extension of the untying agreement but with wider scope and with tougher enforcement; it would need to prevent anti-competitive practices and support the agreement to and enforcement of taxes and subsidies. It might be sufficient to establish a regulator using evidence and data to shame donor countries into better behaviour (possibly a new role for the DAC), or it might be necessary to establish binding rules backed by contractual or treaty obligations. 


\section{CON CLUSIO N S}

99. Aid makes a positive difference to millions of lives every day. Aid works, but it could work much better.

100. Efforts to improve the aid system rely too heavily on planning. Planning works best either when the objectives of each organisation are the same, or when there is an enforcement mechanism. Neither is the case among aid agencies. Aid agencies have diverse and sometimes competing objectives, and there is nothing that can require them to do something that they do not perceive to be in their interests. Planning and donor coordination will not resolve the challenges of incomplete information, a broken feedback loop, and principal-agent problems in the aid delivery chain.

101. The aid system reflects a deep-seated political equilibrium between the interests of donors and recipients. Reforms that involve moving away from that equilibrium will not succeed and may contribute to eroding public and political support for aid; substantive, longterm change depends on finding ways to change the equilibrium.

102. We should apply the following two tests to any proposal for improving the aid system:

a. Does this proposal merely wish away the underlying problem, or does it help to change the political economy of aid?

b. Does this proposal help to instil mechanisms that will allow the aid system to evolve over time?

101. Aid funders could make more use of market incentives to encourage innovation and efficient delivery of services, and to close down ineffective or unnecessary programmes and organisations. But markets require explicit contracts and prices, so this will require unbundling of aid funding from delivery and more rigorous measurement of results. Markets will improve the effectiveness of aid only if the interests of the purchaser can be aligned with the interests of the intended beneficiaries.

103. Networks hold the promise of increasing and improving information and to reducing transactions costs, to help to close the feedback loop between beneficiaries and funders, and providing a platform for collaboration.

104. Using markets and networks together more effectively may permit decentralized and uncoordinated decision-making to produce collectively beneficial outcomes in transparent and regulated markets. Aid agencies would find it politically difficult to pursue ineffective approaches (such as tied aid, or lack of predictability) if there were greater transparency and better measurement of results. A more decentralized system would give substance to the country-led approach to development, enabling the governments and citizens of developing countries to exercise real leadership over their own development programmes. 
105. The aid architecture will not be reformed by intelligent design. The record of international committees in promoting reform, picking winners and closing down poorly performing organisations does not give cause for optimism. Instead, policy-makers should focus on creating the conditions for a new ecosystem of aid institutions to evolve. Evolution requires variation and selection, so reformers should look for incentives and funding arrangements which promote innovation and reward success.

106. A ollaborative mark et would invest in the standards and systems needed to support a network economy in development, encouraging the sharing of ideas and knowledge, and underpinning a more transparent and accountable market for the delivery of development services. The collective action challenge of putting such a framework in place, while not trivial, is simpler by far than the current burden of day-to-day coordination and collective decision making in aid.

\section{OWEN BARDER}

OCTO BER 2009 


\section{REFERENCES}

Acharya, Arnab, Ana Teresa Fuzzo de Lima, \& Mick Moore (2004). Proliferation and Fragmentation: Transaction Costs and the Value of Aid. Journal of D evelopment Studies, 42(1): 1-21.

Alesina, Alberto, \& D avid D ollar (2000). Who Gives Foreign Aid to Whom and Why? Journal of E conomic G rowth, 15(1): 33-63.

Bandyopadhyay, Sanghamitra, \& Howard J. Wall (2007). The determinants of aid in the postcold war era. F ederal Reserve Bank of St. L ouis, Nov 2007, pages 533-548.

Banerjee, Abhijit et al (2007). Making A id W ork. The MIT Press. 2007.

Barder, O wen (2009). What is Poverty Reduction? C enter for G lobal D evelopment W orking Paper 170

Bendor, Jonathan (1988). Formal Models of Bureaucracy. British Journal of Political Scienœ, pp 353-395

Benkler, Y oki. (2006). The W ealth of N etwork s: H ow social production transforms mark ets and freedom. New Haven and London: Y ale University Press.

Bevan, G wyn \& Christopher Hood (2006). Have targets improved performance in the English National Health Service? British M edical Journal 2006;332:419-22.

Birdsall, Nancy, William Savedoff, \& Katherine Vyborny (2009). Cash on D elivery: A N ew A pproach to F oreign A id W ith an A pplication to Primary Schooling. Center for Global D evelopment 2009.

Brautigam, D eborah \& Stephen Knack (2004). Foreign aid, institutions, and governance in sub-Saharan Africa. E conomic D evelopment and C ultural Change, vol. 52, pp255-285.

Bourguignon, Francois \& Mark Sundberg (2007). Aid Effectiveness-O pening the Black Box. A merican E conomic Review, vol 97, no 2, pp316-321.

Burnside, Craig \& D avid D ollar (2000). Aid, Policies, and G rowth. A merican E conomic Review, vol 90(4), pp847-68.

Celasun, Oya, \& Jan Walliser. (2008). Predictability of Aid: D o Fickle D onors Undermine Aid Effectiveness? E conomic Policy (July 2008): 545-94.

Clemens Michael, Steve Radelet \& Rikhil Bhavnani (2004). Counting chickens when they hatch: the short-term effect of aid on growth, C enter for $\mathrm{G}$ lobal D evelopment W orking Paper N 044.

Coase, Ronald (1937). The Nature of the Firm. E conomica, Vol 4 pp 386-405.

Cohen, D on, \& Bruno Laporte (2004).The Evolution of the Knowledge Bank. KM M agazine, March 2004 (http:/ / www.kmmagazine.com)

Collier, Paul (2007). The Bottom Billion. New Y ork: Oxford University Press. 
Collier, Paul, \& D avid D ollar (2002). Aid allocation and poverty reduction, E uropean E conomic Review, vol45(1), pp1-26.

Collier, Paul, \& Anke Hoeffler (2004). A id, Policy and G rowth in post-conflict societies. E uropean E conomic Review, Volume 48, Issue 5, O ctober 2004, pp 1125-1145

Cooper, Zachary N, Alistair McG uire, Simon Jones, \& Julian Le Grand (2009). Equity, waiting times, and NHS reforms: retrospective study. British M edical Journal 2009;339:b3264

D algaard, Carl-Johan, Henrik Hansen, \& Finn Tarp (2004). On The Empirics of Foreign Aid and G rowth. The E onomic Journal, Pages F191 - F216

De Renzio, Paulo, \& Andrew Rogerson (2005). Power to Consumers? A Bottom-Up Approach to Aid Reform. Overseas D evelopment Institute O pinion 40. May. London: ODI.

De Waal, Alex (1997). Famine crimes: politics \& the disaster relief industry in A frica. Indiana University Press, O ctober 1997.

Djankov, Simeon, Jose Montalvo, \& Marta Reynal-Q uerol (2008). The curse of aid. Journal of E conomic G rowth, 13(3):169-194

D ollar, D avid, \& Victoria Levin (2006). The Increasing Selectivity of Foreign Aid, 19842003. W orld D evelopment 34(12):2034-2046.

D uflo, Esther, Rachel Glennerster \& Michael Kremer (2007). Using Randomization in D evelopment Economics Research: A Toolkit. M IT Poverty A cion L ab, January 2007

Easterly, William (2001).The Elusive Quest for Growth: Economists' Adventures and Misadventures in the Tropics. MIT Press, Cambridge MA.

Easterly, William (2002). The Cartel of G ood Intentions: Bureaucracy vs. Markets in Foreign Aid. C enter for G lobal D evelopment W ork ing Paper N 0. 4.

Easterly, William (2007). The W hite Man's Burden. Penguin Press.

Easterly, William, \& Tobias Pfutze (2007). Where D oes the Money G o? Best and Worst Practices in Foreign Aid. Brook ings Institution W ork ing Paper.

EU Council (2007). Code of Conduct on Complementarity and Division of Labour in D evelopment Policy.

Fielding, D avid, \& G eorge Mavrotas (2005). The V olatility of Aid. E onomics D iscussion Papers N 0.0508. University of O tago, D unedin, New Zealand.

Fielding, David, \& G eorge Mavrotas (2008). Aid Volatility and D onor-Recipient Characteristics in 'D ifficult Partnership Countries'. E conomica, 75(299): 481-94.

Gillmor, D an (2004). W e the M edia. G rassroots Journalism by the People for the People. Beijng. Cambridge: O 'Reilly.

Glennie, Jonathan (2008). The Trouble W ith A id. Zed Books. 
Global Partnership for O utput Based Aid (2008). What is O utput Based Aid?

Guillaumont, Patrick, \& Lisa Chauvet (2001). Aid and Performance: A Reassessment. Journal of D evelopment Studies, Vol 37(6),pp 66 - 92

Hansen, Henrik (2004).The Impact of External Aid and External D ebt on Growth and Investment. In Tony Addison, Henrik Hansen and Finn Tarp (eds), D ebt R elief for Poor C ountries. New York: Palgrave Macmillan. Chapter 7, pp. 134-157.

Hanson, Robin, et al (2008). The Promise of Prediction Markets. Science 320(5878):877-8878, May 16, 2008.

Kharas, Homi (2008). Measuring the Cost of Aid Volatility. Brook ings Institution W ork ing Paper.

Klein, Michael, \& Tim Harford (2005). The Market for A id. Washington D .C.: IFC.

Knack, Stephen (2001). Aid D ependence and the Q uality of G overnance: Cross Country Empirical Tests. Southern E conomic Journal 68(2):310-329.

Knack, Stephen, \& Aminur Rahman (2004).D onor Fragmentation and Bureaucratic Q uality in Aid Recipients. W orld Bank Policy Research W orking Paper 3186.

Kremer, Michael, \& Ted Miguel (2004). The Illusion of Sustainability. BRE A D W ork ing Paper N o. 091, November 2004 (Revised August 2006)

Laffont, Jean-Jacques, \& D avid Martimor (2002). The Theory of Inoentives: The Principal-agent M odel. Princeton University Press, US

Lensink, Robert, \& O liver Morrissey (2000). Aid instability as a measure of uncertainty and the positive impact of aid on growth.Journal of D evelopment Studies, 36 (2000), pp 31-49.

Loxley, John, \& Harry Sackey (2008). A id E ffectiveness in A frica. African D evelopment Review 20(2):163-199.

Martens Bertin, Uwe Mummert, Peter Murrell, Paul Seabright \& Elinor O strom (2003). The Institutional $\mathrm{E}$ conomics of $\mathrm{F}$ oreign $\mathrm{A}$ id. Cambridge University Press.

Martens, Bertin (2005). Why D o Aid A gencies Exist? D evelopment Policy Review, Vol 23:6. pp 643-663

Minoiu, Camelia, \& Sanjay G. Reddy (2009). D evelopment Aid and Economic G rowth: A Positive Long-Run Relation. International M onetary F und W ork ing Paper 09/ 118.

Milner, Helen (2004). Why Multilateralism? Foreign Aid and D omestic Principal-Agent Problems. Columbia U niversity, NY (2004).

Moe, Terry (1997) The positive theory of public bureaucracy. In Dennis Mueller, Perspectives on Public Choice: A Handbook. Cambridge University Press 1997, 455480.

Moss, Todd, Gunilla Pettersson, \& Nicolas van deWalle (2006). An Aid-Institutions Paradox? A Review Essay on Aid D ependence and State Building in Sub-Saharan Africa. C enter for G lobal D evelopment W orking Paper 74. 
Moyo, D ambisa (2008) D ead A id. Macmillan.

Niskanen, William (1968). The Peculiar Economics of Bureaucracy. American Economic Review Papers and Proceedings 58: 293-305.

North, D ouglass (1990). A Transaction Cost Theory of Politics. Journal of Theoretical Politics, 2:4, pp. 355-67.

OECD D AC (2001). Guidelines for Poverty Reduction.

OECD D AC (2005). The Paris D eclaration.

OECD D AC (2008a). 2008 Survey on Monitoring the Paris D eclaration.

OECD D AC (2008b). The Accra Agenda for Action.

Olson, Mansur (1965). The L ogic of C ollective A ction. Cambridge, Mass.: Harvard University Press.

O strom, Elinor, et al (2002). Aid, Incentives and Sustainability: An Institutional Analysis of D evelopment Cooperation, SID A Studies in E valuation 2002.

Radelet, Steve (2006). A Primer O n Foreign Aid. C enter for G lobal D evelopment W ork ing paper $\mathrm{N} 092$.

Rajan, Raghuram, \& Arvind Subramanian (2005). Aid and G rowth: what does the crosscountry evidence really show? N BE R W ork ing Paper N 0. W 11513

Rajan, Raghuram, \& Arvind Subramanian (2005). "What Undermines Aid's Impact on G rowth?" NBER Working Papers 11657 National Bureau of Economic Research, Inc.

Rogerson, Andrew (2004). "The International Aid System 2005-2010: Forces For and Against Change." ODI Working Paper 235. Overseas D evelopment Institute, London.

Rogerson, Andrew (2005). "What if Aid harmonisation and alignment occurred exactly as intended? A reality check on the Paris Forum on Aid Effectiveness." Paper prepared for the ODI-D evelopment Centre Workshop on Research Perspectives on Aid Architecture.

Roodman David (2007). The Anarchy of Numbers: Aid, development and Cross-country Empirics. The W orld Bank E conomic Review 2007 21(2):255-277

Sachs, Jeffrey (2005a). Investing in D evelopment - A Practical Plan to A chieve the Millennium D evelopment $G$ oals. UN Millennium Project Report to the UN Secretary-G eneral. New York.

Sachs, Jeffrey (2005b). The end of poverty: how we can make it happen in our lifetime. London.

Savedoff, William, Ruth Levine \& Nancy Birdsall (2006) W hen W ill W e E ver L earn? Center for Global D evelopment, Washington DC. 
Shafik, Minouche (2009) From Architecture to Networks: Aid in a World of Variable G eometry. Ideas4D evelopment. June 2009.

Smith, Adam (1776). A n E nquiry into the $\mathrm{N}$ ature and $\mathrm{C}$ auses of the $\mathrm{W}$ ealth of $\mathrm{N}$ ations

Surowiecki, James (2004). The wisdom of crowds: Why the many are smarter than the few and how collective wisdom shapes business, economies, societies and nations. New Y ork: D oubleday.

Tapscott, D on and Anthony D. Williams (2006), W ik inomics: H ow M ass C ollaboration Changes E verything

Tirole, Jean. (1994). The internal organization of government. Oxford Economic Papers. 46,1-29.

Williamson, O liver (2000). The New Institutional Economics: Taking Stock, Looking A head. Journal of E conomic Literature, Vol. 38, No. 3 (Sep., 2000), pp. 595-613

World Bank (2004). Making Services Work For Poor People. W orld D evelopment Report.

World Bank (2006). "A Review of the Use of O utput-Based Aid Approaches"

Wood, Adrian (2008). Looking ahead optimally in allocating aid. W orld D evelopment,, Vol 36 (7), pp 1135-1151

Wood, Adrian (2008). How D onors Should Cap Aid in Africa. Financial Times, September $4^{\text {th }}$ 2008. 